\title{
ADAPTATION OF A TEACHER TRAINING PROGRAMME FOR CHARACTER EDUCATION TO THE LATVIAN CONTEXT
}

\author{
Manuel Joaquín Fernández González \\ University of Latvia, Latvia \\ Svetlana Surikova \\ University of Latvia, Latvia \\ Tamara Pigozne \\ University of Latvia, Latvia
}

\begin{abstract}
This paper presents an analysis of the quality of the adaptation of the transnational teacher training programme for character education "Arete catalyst" to the socio-cultural context of Latvia. Based on the theory of cultural adaptation of educational programmes, and on a qualitative analysis of documentary sources, the quality of the adaptation was discussed by comparing the features of the adapted programme with Latvian societal needs and policy makers' guidelines for character education (research question 1), and with the legal and institutional requirement for teacher training (research question 2). The findings revealed that the adapted Latvian programme responds widely to the needs of Latvian society and of the educational sector regarding character and virtue education, and addresses values and virtue education, as foreseen in the governmental guidelines for upbringing at school. It also complies with the Law of Education and the regulations of the Cabinet of Ministers regarding the professional development of teachers, and with the rules for approval and implementation of teacher training programmes at the University of Latvia. The adaptation process described can be useful for academics adapting existing programs to new socio-cultural contexts. This work should be continued by piloting and refining the adapted programme.
\end{abstract}

Keywords: Arete catalyst, character education, professional competence development, programme adaptation, teachers' further education, teacher training programme, values and virtue education.

\section{Introduction}

Character education is widely recognized as an essential part of $21^{\text {st }}$ century school education (e.g., Fadel et al., 2015; Retnowati et al., 2018). However, although there is a number of teacher training for character 
education initiatives, such as the work of the association Character.org in the USA ${ }^{1}$ and the Jubilee Centre for Character and Virtues in United Kingdom ${ }^{2}$, many teachers feel that they are not properly educated for this task (Mathison, 1999; Revell \& Arthur, 2007; Brunn, 2014; Fernández González, 2019).

In Latvia also there is a number of teacher training courses in this field (for a recent review, see Surikova \& Pigozne, 2018, pp. 12-14), but these initiatives fail to address holistically the different aspects of teacher training for character education: some are theory-oriented, others focus on the work in the classroom or in concrete subject matters, some address the education of a single virtue, while others look at the integration of values in the school life. And most of those teacher training proposals scarcely address the flourishing of personality of teachers themselves.

For facing these challenges, in 2018-2019, a transnational teachers' training programme for character education (Arete Catalyst, 2019) was elaborated within the Erasmus + project "Supporting teachers for developing intra-personal competencies and character education at school - Arete Catalyst", a strategic partnership involving Latvia, Estonia and Spain. The programme was elaborated and reviewed by a body of 35 experts from different sectors: educational researchers, schoolteachers and headmasters, education policy makers, and educational supervisors. It adopted multifaceted perspectives, including insights from 'philosophy for children' (Lipman, 1982; Trickey \& Topping, 2004), 'coexistence education' (Delors et al., 1996), and 'virtue ethics' (MacIntyre, 2013; Kristjánsson, 2019), and it was based on a research of best practices in the field and a need analysis in the field of character education in the partner countries (Verdeja Muñiz \& García-Sampedro Fernández-Canteli, 2018).

The programme "Arete catalyst" adoptes the Jubilee Centre for Character and Virtues (2017) definition of character as a set of personal traits or dispositions that produce specific moral emotions, inform motivation and guide conduct. Character education includes all explicit and implicit educational activities that help young people develop positive personal strengths called virtues (Jubilee Centre for Character and Virtues, 2017, p. 2). The programme "Arete catalyst" has a core of fundamental fixed elements which define its academic identity, and several flexible elements which allow programme adaptation for implementation in different sociocultural contexts, countries, regions or schools. In 2019, the programme was adapted to the Latvian educational context by the University of Latvia (UL) as a professional competence development (PCD) programme

\footnotetext{
${ }^{1}$ https://www.character.org/

${ }^{2}$ https://www.jubileecentre.ac.uk/
} 
for teachers called "Improving pedagogues' transversal competencies for promoting students' character education and excellence" (herein after: the Latvian programme). The Latvian programme includes four modules ('Communication', 'Theory and Self-Understanding', 'Methodology' and 'Assessment') and a set of activities aligned with the learning outcomes and the assessment, including a character education project at school.

This paper reports the main issues that were faced during the programme adaptation to the Latvian context, highlighting how the leaders of the adaptation process dealt with Latvian societal, juridical, and institutional specificity. The insights presented in this paper might be useful for academics involved in the adaptation of existing programmes to new, different socio-cultural contexts, and it could serve as a thought-guide and a source of practical advice for those undertaking such a challenging endeavour.

\section{Theoretical background: Programme adaptation theory}

Culture influences the way in which individuals see themselves and their environment at every level of the social-ecological system (Greene \& Lee, 2002). Nowadays, acculturation and adaptation (Ward, 1996; Berry \& Sam, 1997; Ward \& Geeraert, 2016) are two major concerns in social sciences in a globalized world marked by an increasing mobility. Cultural adaptation has implications in many education and training areas, such as the internationalization of higher education (e.g., Shafaei \& Razak, 2016), transfer of interventions in real practice settings (e.g. Marsiglia \& Booth, 2015) and the transfer of teaching and learning in new contexts (Leberman \& McDonald, 2016).

In the specific field of transfer of teacher training, McDonald (2016) argues that "cultural characteristics and values can significantly influence the outcome of training" (p. 105). Efficient transfer of teacher training needs to be viewed in a systemic manner (Broad, 2005), which includes considering programme relevance for the students, school, community and culture, as well as the barriers and facilitators of transfer and the ways of dealing with them (McDonald, 2001, pp. 93-94).

The cultural adaptation of teacher training programmes is a challenging process. Barrera and Castro (2006) proposed a heuristic framework for the cultural adaptation of medical interventions that could be useful also in educational contexts. They described an adaptation sequence of different phases: (a) information gathering, (b) preliminary adaptation design, (c) preliminary adaptation tests, and (d) adaptation refinement. This framework was used in this study about teacher training programme adaptation, addressing the phases (a) i.e., information gathering about 
the context of the adaptation, and (b), i.e., the description of the preliminary adaptation design. The piloting of the adapted programme (c) and its refinement (d) will make the object of another paper.

In this study, the gathering of contextual information (a) focussed on adaptation facilitators and barriers at different levels of the socioecological system in Latvia, namely, the societal level, the policy makers' level and the institutional level. For the design of adapted programme (b), constructive alignment theory (Biggs, 2011) was used. Instead of the traditional approach, which focuses on the definition of contents and on teaching and learning methods, the adapters of the programme sought for an alignment between the intended learning outcomes of the programme, the activities to be implemented by the learners, and the assessment tasks.

In order to investigate the quality of the preliminary adaptation design of the programme, in this study the Latvian programme features were checked against the information gathered (at the three levels of the socialecological system) regarding national teacher training requirements and societal and educational needs in the field of character education. The following research questions guided the inquiry:

RQ1. Does the adapted programme correspond to the Latvian societal needs and policy makers' guidelines in the field of character education?

RQ2. Does the adapted programme follow educational policy makers' and institutional (UL) requirements regarding teachers' further education?

\section{Methodology}

For answering the research questions, an initial qualitative analysis of documentary sources was implemented. Sources revealing societal needs and policy makers' guidelines in the field of character education (RQ1) and policy makers' and institutional (UL) requirements regarding teachers' further education (RQ2) were selected and analysed. After that, a comparison between the program features and the findings of the document analysis was implemented, discussing compliance or disagreement between them.

\section{Findings and Discussion}

For clarity, the findings and their discussion are presented by research questions. For each question, the sources analysed, and a summary of the relevant information gathered are presented first, followed by a discussion of the findings in relation to the Latvian programme. 
Information at societal level was gathered from two recent sources: a research report about pupils' moral education in Latvian schools (Fernández González, 2019), and a recent need analysis report addressing the situation of teacher training for character education in Latvia (Surikova \& Pigozne, 2018) elaborated within the "Arete Catalyst" project. Information at policy makers' level was gathered in the Latvian Regulations regarding values and virtue education at school (Cabinet of Ministers, 2016), and in the guidelines of the school content reform project "Competence-based approach to educational content" (Skola2030, 2017).

\section{Latvian societal needs in the field of character education}

Regarding Latvian societal needs in this field, a recent research report (Fernández González, 2019) involving more than 2250 respondents from different educational sectors, reports that:

- 92\% of respondents believe that "schools should develop pupils' characters and encourage good values", and $70 \%$ - that facilitating pupils' moral growth is part of teacher's role.

- However, only $28 \%$ believed that teachers were sufficiently or fully prepared for this work. Differences between sectors were significant $(p=.000)$ : pre-service and in-service teachers were most confident about their preparedness (i.e. $68 \%$ and $58 \%$ ), while only $25 \%$ of school leaders and $16 \%$ of education managers thought that teachers are well prepared for this task.

- There is a necessity to reinforce pre-service and in-service teacher training for values and character education at school. The courses should be practical, based on real situations, and they should also address the flourishing of personality of the teachers themselves.

- In-service teachers need methodological materials and methodological guidelines regarding character education, in line with Latvian legislation and current reforms.

The need analysis report (Surikova \& Pigozne, 2018) identified the following weaknesses and threats in teacher training for character education in Latvia:

- A lack of a unified understanding of the terms related to character and virtue education.

- A lack of teachers' professional competence development (PCD) programmes in this field.

- Given the current educational reforms (Skola2030, 2017), teachers are overloaded. A PCD course on character education should adapt to teachers' lack of time and energy. 
- There is a lack of teacher trainers with the required availability and competence in the field.

\section{Values and virtue education in the Latvian regulations and in the school reform project}

Regarding policy makers, the Cabinet of Ministers' Regulation No. 480 "Guidelines for the upbringing of learners and the procedure for evaluating information, teaching aids, materials and teaching/learning and upbringing methods" (Cabinet of Ministers, 2016) include a set of ten values (No. 4) and twelve virtues (No. 7) to be taught art school. Teachers and students should develop values and virtues in mutual relations (No. 8), and teachers should collaborate with pupils' parents and families (No. 8.2) and with students (No. 8.3). They should also improve their professional competence in upbringing by attending an at least 6 hours long course every 3 years (No. 11).

The current educational reform in Latvia addresses the acquisition of the values and virtues mentioned in the government regulations (Skola2030, 2017, pp. 7-8). It is teachers' responsibility to help students to develop habits (virtues) based on those values (p. 8), and to integrate them in the study process (p. 7), but they can freely organize their work to reach those goal (p. 6). With their behaviour and attitudes, teacher are role models for students' moral growth (p. 15).

\section{Discussion of the findings in relation with the Latvian programme}

As a whole, the Latvian programme responds widely (but not completely) to the identified societal needs and is in line with the guidelines of policy makers. It offers in-service teacher training for character education (without addressing pre-service teacher training). It facilitates teachers' ability to act as moral role models through specific activities addressing teachers' personality flourishing (e.g., activity 2.1. 'Self-awareness and self-reflection'). It is based in practical examples, including the analysis of good practices (e.g., activity 3.2. 'Identifying examples of good practice, generating project ideas for improvement of pedagogues' creativity for character education') and a final practical project. It proposes a unified understanding of the langue of values and virtues and enhances teachers' knowledge of the field throughout the module 'Theory and Self-Understanding'. It also fosters their communicative competence for establishing mutual relations with pupils and their families (module 'Communication'), and addresses the need for methodological materials, 
supporting teachers methodologically for integrating values and virtue education in the study process in the module 'Methodology'. The length of the programme (36 hours) and the distribution of seminars, practical work and lectures is meant to adapt to teachers' availability, but this should be tested practically.

\section{RQ2: Does the adapted programme follow educational policy makers' and institutional (UL) requirements regarding teachers' further education?}

Information at policy makers' level was gathered in the Education Law of the Republic of Latvia (RL) (1998), and in the current regulations of the Cabinet of Ministers of the RL (Cabinet of Ministers, 2018). Information at institutional level was gathered in the normative documents of the UL (University of Latvia, 2018).

\section{Latvian legislation about continuous professional development for teachers}

The Education Law of the RL (1998) stipulates in Section 14 the competence of the Cabinet of Ministers in the field of education, which includes "to confirm, in accordance with pedagogical professions, the requirements for required education and professional qualifications of teachers" (No. 13) and "to determine the procedures for professional competence improvement of teachers" (No. 32). On these bases, the Cabinet of Ministers of the RL (Cabinet of Ministers, 2018) stipulated that teachers should attend a professional competence development (PCD) programme of a least 36 hours every 3 years (No. 15). The No. 18 of this Regulation stipulates that the PCD programme may include such topics as 'upbringing competence' (No. 18.1), the choice of methods and didactics (No. 18.2), and class management (No. 18.3). Those programs can be implemented, among other providers, by higher education institutions providing pedagogical education. The No. 22 stipulates that the provider should indicate the programme goal, objectives, learning outcomes, realization forms, target public, and an implementation plan indicating the number of hours, the topics and the forms and methods of delivering. Participants receive either a Certificate 1 (in Latvian "aplieciba" for programmes shorter than 72 hours) or a Certificate 2 (in Latvian "sertifikäts" for programmes over 72 hours).

\section{Requirements of the UL regarding teachers' further education}

The Centre of Adult Education (CAE) of the Faculty of Education, Psychology and Art (FEPA) coordinates the CPD programmes for teachers 
at the UL. For starting new PCD courses, the CAE applies the standard UL procedure for new study courses (University of Latvia, 2018).

First, the development of the new course is proposed to the head of the department responsible by the director of the study programme with the approval of the dean of the faculty implementing the study programme (University of Latvia, 2018, No. 3). Then the course is elaborated according to the "Study course description form" (University of Latvia, 2018, Annex 2), which includes the information required by law (Cabinet of Ministers, 2018, No. 22) and some additional information, as for example, the study course title, level, number of ECTS, number of contact hours (incl. lectures, seminars, practical assignment and independent study hours), characterization of students' independent work organization and tasks, requirements for awarding credits, criteria for assessing learning outcomes, compulsory reading list, further reading list, and a detailed course content. At the UL, learning outcomes are categorized in 'knowledge', 'skills' and 'competence' (Baranova, 2020, p. 8), and the study course assessment is done in a 10-point scale (University of Latvia, 2018, Annex 4). The next step is the course verification: the full course description is introduced in the electronic system of the UL (LUIS) and it is examined by the Department of Studies and controlled by the responsible of the educational branch. The final step is to proceed to the course approval: first, by a decision of the Council of the Faculty implementing the programme, and then by the Rector who issues the order authorising the implementation of the programme under the request of the Dean, and nominates its director and defines its classification and sources of financing.

\section{Discussion of the findings in relation with the Latvian programme}

The Latvian programme complies fully with the national requirements for teacher training. It was developed and approved according to the No. 22 of the regulation of the Cabinet of Ministers (Cabinet of Ministers, 2018). It last 36 hours, which is the required amount teachers should acquire every 3 years. It directly addresses pupils' upbringing, character education methods and class management. In addition, it includes the topics "elaboration of methodological materials" and teachers' "personality development", which appeared in the previous redaction of this Regulation under the headline "teacher self-experience" (Cabinet of Ministers, 2014, No. 12) and, unfortunately, are not included anymore in the list of topics of PCD programmes in the new edition of the Regulation (Cabinet of Ministers, 2018, No. 18). 
The approval of the Latvian programme at the UL complied also with the standard procedure. The development of the programme was initiated by the programme director with the support of the dean of the FEPA. The programme information, including a reformulation and reorganization of the ILOs in the categories of 'knowledge', 'skills' and 'competence', was introduced in the LUIS system. It should be noted that there were some differences between the "Study course description form" and the description file of the Latvian programme: As a PCD programme, the requirements for the acquisition of the programme were the active participation in seminars (discussions, analysis of case situations, work of groups), the implementation of the independent works (presentations, methodological materials), and the design and implementation of the character education project. The assessment of the modules and activities is not foreseen in a 10-point scale.

Once the Latvian programme was verified by the Department of Studies and the responsible of the educational branch, it was approved by the Council of the Faculty (decision No. 30-2/23 of 28.03.2019), and, under request of the Dean (05.04.2019), was approved by the Rector of the UL (Order No. 1-161 of 23.04.2019). It is currently being implemented as a PCD programme by the CAE at the UL. Under completion of the programme, participants receive a Diploma delivered by the UL. It should be noted that the UL is taking measures to reduce fragmentation of the higher education programmes and to develop higher quality study programmes, following a national trend (specific objective 8.2.1 "To reduce fragmentation of study courses and to strengthen sharing of resources" of the priority axis "Education, Skills and Lifelong Learning" of the national Operational Programme "Growth and Employment"), and with support from EU funds (European Commission, 2019, pp. 8-9). In this context, the acceptation and approval of a new teacher training programme counts as an evidence of the quality and necessity of the new Latvian programme.

\section{Conclusions}

In 2019, the international teacher training programme "Arete catalyst" was adapted as a Latvian programme by a team of experts of the UL. This study analysed the quality of this adaptation, considering needs and requirements at societal level, the policy makers' level and the institutional level.

The adapted Latvian programme responds widely (but not completely) to Latvian societal needs and the needs of the educational sector regarding character and virtue education, offering an in-service teacher training for character education that improves teachers' understanding of the langue 
of values and virtues, enhances their personal flourishing, is based on real situations, enhances their methodological skills in the field and is appropriate to teachers' availability. It also addresses values and virtue education, as foreseen in the governmental guidelines about pupils' upbringing and in the normative documents of the current educational reform.

The Latvian programme complies with the orientations and guidelines of educational policy makers regarding the professional development of teachers, offering a PCD programme fully in line with the Law of Education and the regulations of the Cabinet of Ministers. The programme complies also with the requirements and procedures for programme development and implementation of the UL, which is intended to implement the Latvian programme.

It can be concluded that the adaptation of the programme "Arete catalyst" to the Latvian socio-cultural context was successfully implemented. Further research directions could include piloting and refining the Latvian programme and completing it with methodological guidelines for facilitating the implementation of character education at school.

\section{Acknowledgements}

Research founded by the Erasmus + project "Supporting teachers for developing intra-personal competencies and character education at school - Arete Catalyst" (2017-2019), project number 2017-1-LV01KA201-035435, by the European Regional Development Fund within the post-doctoral project "Arete school" (2017-2020), project number 1.1.1.2/VIAA/1/16/071, and by the University of Latvia within the research project "Human, technologies and quality of education" (2016-2020), project number ZD2010/AZ22, conducted at the Faculty of Education, Psychology and Art.

\section{References}

Arete Catalyst. (2019). "Arete catalyst": Teacher training program for enhancing pupils' flourishment at school (Intellectual output No 2). https://www.pzi.lu.lv/fileadmin/ user_upload/lu_portal/projekti/pzi/ARETE/Arete_Catalyst_Programme_EN.pdf.

Baranova, S. (2020). Handbook of formulating, mapping and evaluating learning outcomes. Latvijas Universitātes Studiju departaments. https://issuu.com/inta.deke/docs/ studiju_rezultatu_rokasgramata_2020.

Barrera, M., \& Castro, F. G. (2006). A heuristic framework for the cultural adaptation of interventions. Clinical Psychology: Science and Practice, 13(4), 311-316. https://doi. org/10.1111/j.1468-2850.2006.00043.x. 
Berry, J. W., \& Sam, D. L. (1997). Acculturation and adaptation. In J. W. Berry, M. H. Segall, \& C. Kagitcibasi (Eds.), Handbook of cross-cultural psychology: Vol. 3. Social Behavior and Applications (pp. 291-326). Allyn and Bacon.

Biggs, J. B. (2011). Teaching for quality learning at university: What the student does. McGraw-Hill Education.

Broad, M. L. (2005). Beyond transfer of training: Engaging systems to improve performance. Pfeiffer.

Brunn, P. (2014). Pedagogy for the whole child: The Development Studies Centre's approach to academic, moral and character education. In L. Nucci, \& D. Narvaez (Eds.), Handbook of moral and character education (pp. 263-271). Routledge.

Cabinet of Ministries Regulation regarding teachers' mandatory education and vocational qualification, and teachers' professional competence development procedures, CM Regulation No 662, 28.10.2014, Prot. No 58 5.§ (2014). https://www.vestnesis.lv/ op/2014/219.6.

Cabinet of Ministers Guidelines for the upbringing of learners and the procedure for evaluating information, teaching aids, materials and teaching/learning and upbringing methods, CM Regulation No 480, 15.07.2016, Prot. No 36 34.§ (2016). https://www. vestnesis.lv/op/2016/141.4.

Cabinet of Ministries Regulation regarding teachers' mandatory education and vocational qualification, and teachers' professional competence development procedures, CM Regulation No 569, 11.09.2018, Prot. No 42 14.§ (2018). https://www.vestnesis.lv/ op/2018/182.6.

Delors, J., Al Mufti, I. A., Amagi, I., Carneiro, R., Chung, F., Geremek, B., Gorham, W., Kornhauser, A., Manley, M., Padrón Quero, M., Savane, M. A., Singh, K., Stavenhagen, R., Won Suhr, M., \& Nanzhao, Z. (1996). Learning: The treasure within. Report to UNESCO of the International Commission on Education for the Twenty-first Century. UNESCO Publishing. https://unesdoc.unesco.org/ark:/48223/pf0000110780.

Education Law of the Republic of Latvia. (1998). https://likumi.lv/ta/en/en/ id/50759-education-law.

European Commission. (2019). Education and training monitor 2019 Latvia. Publication Office of the European Union. https://ec.europa.eu/education/sites/education/files/ document-library-docs/et-monitor-report-2019-latvia_en.pdf.

Fadel, C., Bialik, M., \& Trilling, B. (2015). Four-dimensional education: The competencies learners need to succeed. CreateSpace Independent Publishing Platform.

Fernández González, M. J. (2019). Moral education of pupils in Latvian schools: The views of parents, teachers, future teachers, heads of schools and education boards. DSpace, University of Latvia Repository. https://dspace.lu.lv/dspace/handle/7/46498.

Jubilee Centre for Character and Virtues. (2017). A framework for character education in schools. https://www.jubileecentre.ac.uk/userfiles/jubileecentre/pdf/charactereducation/Framework\%20for\%20Character\%20Education.pdf.

Kristjánsson, K. (2019). Flourishing as the aim of education: A neo-Aristotelian view. Routledge.

Leberman, S., \& McDonald, L. (2016). The transfer of learning: Participants' perspectives of adult education and training. CRC Press.

Lipman, M. (1982). Philosophy for children. Thinking: The Journal of Philosophy for Children, 3(3/4), 35-44. 
MacIntyre, A. (2013). After virtue. A\&C Black.

Marsiglia, F. F., \& Booth, J. M. (2015). Cultural adaptation of interventions in real practice settings. Research on Social Work Practice, 25(4), 423-432. https://doi. org/10.1177/1049731514535989.

Mathison, C. (1999). How teachers feel about character education: A descriptive study. Action in Teacher Education, 20(4), 29-38. https://doi.org/10.1080/01626620.1999.10 462932.

McDonald, B. L. (2001). Transfer of training in a cultural context: A Cook Islands study [Doctoral dissertation, Victoria University of Wellington]. Wellington Faculty of Education Theses and Dissertations Archive. https://www.wgtn.ac.nz/education/pdf/ lex-mcdonald.pdf.

McDonald, B. L. (2016). Transfer of training in a cultural context: A Cook Islands teachers' professional development case study. In S. Leberman, \& L. McDonald (Eds.), The transfer of learning: Participants' perspectives of adult education and training (pp. 73-87). Routledge.

Retnowati, E., Ghufron, A., \& Pierawan, A. C. (Eds.). (2018). Character education for 21st century global citizens. Routledge. https://doi.org/10.1201/9781315104188.

Revell, L., \& Arthur, J. (2007). Character education in schools and the education of teachers. Journal of Moral Education, 36(1), 79-92. https://doi.org/10.1080/03057240701194738.

Shafaei, A., \& Razak, N. A. (2016). Internationalisation of higher education: Conceptualising the antecedents and outcomes of cross-cultural adaptation. Policy Futures in Education, 14(6), 701-720. https://doi.org/10.1177/1478210316645017.

Skola2030. (2017). Education for modern competence: Description of study content and approach. http://www.izm.gov.lv/images/aktualitates/2017/Skola2030Dokuments.pdf.

Surikova, S., \& Pigozne, T. (2018). Transversal competences and character education in Latvia: A needs analysis report. DSpace, University of Latvia Repository. https://dspace. lu.lv/dspace/handle/7/49011.

Trickey, S., \& Topping, K. J. (2004). 'Philosophy for children': a systematic review. Research papers in Education, 19(3), 365-380. https://doi.org/10.1080/026715204200 0248016.

University of Latvia. (2018). Procedures for the development and updating of study courses at the University of Latvia. Order No 1/277 of 10.08.2018.

Verdeja Muñiz, M., \& García-Sampedro Fernández-Canteli, M. (Eds.). (2018). A needs analysis report: Mapping of teachers' practices and expectations in the field of pupils' intrapersonal competencies and character education in Latvia, Estonia and Spain (Intellectual output No 1). https://www.pzi.lu.lv/fileadmin/user_upload/lu_portal/projekti/pzi/ ARETE/Arete_Catalyst_Report_EN.pdf.

Ward, C. (1996). Acculturation. In D. Landis \& R. S. Bhagat (Eds.), Handbook of intercultural training (pp. 124-147). Sage Publications, Inc.

Ward, C., \& Geeraert, N. (2016). Advancing acculturation theory and research: The acculturation process in its ecological context. Current Opinion in Psychology, 8, 98-104. https://doi.org/10.1016/j.copsyc.2015.09.021. 